\title{
Research on the SCS-CN initial abstraction ratio using rainfall-runoff event analysis in the Three Gorges Area, China
}

\author{
Zhi-Hua Shi $^{\text {a,b }}$, Li-Ding Chen ${ }^{\text {b,* }}{ }^{\text {, Nu-Fang Fang }}{ }^{\text {a }}$, De-Fu Qin ${ }^{\text {c }}$, Chong-Fa Cai ${ }^{\text {a }}$ \\ ${ }^{a}$ Key Lab of Subtropical Agriculture E' Environment of Ministry of Agriculture, Huazhong Agricultural University, Wuhan 430070, PR China \\ b State Key Laboratory of Urban and Regional Ecology, Research Center for Eco-environmental Sciences, Chinese Academy of Sciences, P.O. Box 2871, Beijing 100085, PR China \\ c Soil and Water Conservation Bureau of Zigui County, Hubei Province 443600, PR China
}

\section{A R T I C L E I N F O}

\section{Article history:}

Received 1 April 2008

Received in revised form 26 November 2008

Accepted 30 November 2008

\section{Keywords:}

SCS-CN method

Direct runoff

Initial abstraction ratio

Rainfall-runoff events

\begin{abstract}
A B S T R A C T
The Soil Conservation Service Curve Number (SCS-CN) method is widely used for predicting direct runoff from rainfall. The ratio of initial abstraction (Ia) to maximum potential retention $(S)$ was assumed in its original development to be equal to 0.2 in SCS-CN method. The constant initial abstraction ratio is the most ambiguous assumption and requires considerable refinement. The objectives of this study were (1) to determine the initial abstraction ratio, in an experimental watershed in the Three Gorges Area of China, by analyzing measured rainfall-runoff events; (2) to compare the performance of the traditional and modified $I a / S$ values with observed rainfall-runoff data. The dataset consisted of 6 years of rainfall and runoff measurements from the experimental watershed. The results indicated that the Ia/S values, using event rainfall-runoff data, varied from 0.010 to 0.154 , with a median of 0.048 . The average initial abstraction ratio of the watershed was equal to 0.053 . The standard SCS-CN method underestimates large runoff events, yielded a slope of the regression line of 0.559 and an intercept of 0.301 . The modified Ia/S value was about 0.05 that better predicted runoff depths with an $R^{2}$ of 0.804 and a linear regression slope of 0.834 . It also improved model efficiency coefficient $(E)$ to 0.768 compared with 0.482 for traditional $I a / S$ value. This Ia/S-adjusted SCS-CN method appears to be better appropriate for runoff prediction in the Three Gorges Area of China.
\end{abstract}

(c) 2008 Elsevier B.V. All rights reserved.

\section{Introduction}

Estimation of surface runoff is essential for the assessment of water yield potential of a watershed, planning of soil and water conservation measures, reducing the sedimentation and flooding hazards downstream. Although many hydrologic models are available for the estimation of direct runoff from storm rainfall, most models are limited because of their intensive input data and calibration requirements. Thus, models used for management decisions should be simple and unpretentious, with few data requirements and clearly stated assumptions (Grayson et al., 1992). The Soil Conservation Service Curve Number (SCS-CN) method, developed by the USDA-Soil Conservation Service (SCS, 1972), is widely used for the estimation of direct runoff for a given rainfall event from small agricultural watersheds. Due to its low input data requirements and its simplicity, many watershed models such as CREAMS (Knisel, 1980), AGNPS (Young et al., 1989), EPIC (Sharpley and Williams, 1990), and SWAT (Arnold et al., 1996) use this method to determine runoff. It has, however, been recently extended for other applications, including sediment

\footnotetext{
* Corresponding author. Research Center for Eco-environmental Sciences, Chinese Academy of Sciences, P.O. Box 2871, Beijing 100085, China. Tel.: +86 10 62943840; fax: +8610 62923557.

E-mail address: liding@rcees.ac.cn (L.-D. Chen).
}

yield or soil moisture modeling and the feedback on CN (Mishra et al., 2006a,b; Reshmidevia et al., 2008; Singh et al., 2008).

The SCS-CN (SCS, 1972) method is based on a water balance and two fundamental hypotheses which can be expressed, respectively, as

$P=I a+F+Q$

$\frac{Q}{P-I a}=\frac{F}{S}$

$I a=\lambda S$

where $P$ is the precipitation ( $\mathrm{mm}$ ), I $a$ is the initial abstraction ( $\mathrm{mm}), F$ is the cumulative infiltration excluding $I a, Q$ is the direct runoff $(\mathrm{mm})$, $S$ is the potential maximum retention after beginning of the runoff $(\mathrm{mm})$, and $\lambda$ is the initial abstraction ratio. Combining Eqs. (1), (2), and (3) gives an expression for $Q$ :

$Q=\frac{(P-I a)^{2}}{P+S-I a}$

Eq. (4) is valid for $P>I a$, otherwise, $Q=0$. The parameter $S$ in Eq. (4) is defined as

$S=\frac{25400}{\mathrm{CN}}-254$ 
where $S$ is in $\mathrm{mm}$ and $\mathrm{CN}$ (curve number) varies based on one of three antecedent soil moisture conditions: curve number I-dry, curve number II-average, and curve number III-wet.

Traditionally, Ia is often set equal to $0.2 S$ in Eq. (3). Since the history and documentation of this relationship are obscure, the assumption of $I a=0.2 S$ has been frequently questioned for its validity and applicability, invoking a critical examination of the Ia-S relationship for pragmatic applications. Mishra et al. (2006a,b), employing a large dataset of 84 small watersheds (area $=0.17$ to 71.99 ha) of USA, investigated a number of initial abstraction (Ia)-potential maximum retention $(S)$ relations incorporating antecedent moisture as a function of antecedent precipitation. Jain et al. (2006) reviewed the Ia-S relationship, and proposed a new non-linear relation incorporating storm rainfall $(P)$ and $S$. Ponce and Hawkins (1996) suggest that the fixing of the initial abstraction ratio at 0.2 may not be the most appropriate number, and that it should be interpreted as a regional parameter.
The Three Gorges Area (TGA) covers 21 counties and cities in central China's Hubei Province and Chongqing Municipality with a total area of $58,800 \mathrm{~km}^{2}$. Due to long-term human activities including overuse and inappropriate development, soil erosion has become a serious issue. It was reported that annual soil loss in the TGA is about 157 million t, of which 40 million $t$ are delivered to the Yangtze River by $700 \mathrm{t} \mathrm{km}^{-2} \mathrm{yr}^{-1}$ (Shi et al., 1992; Lu and Higgitt, 1998). In addition, the Three Gorges Dam being built to harness power from the Yangtze River is also a matter of hot debate. In order to decrease soil erosion, maintain land productivity and improve environmental quality, a series of soil conservation practices are being implemented, including tree plantations, establishment of pasturelands, and construction of terraces. In the TGA, most agricultural watersheds are ungauged, having no record whatsoever of rainfall-runoff processes. An appropriate method to predict surface runoff from watershed is, therefore, essential for the design of these soil conservation works. The SCS-CN

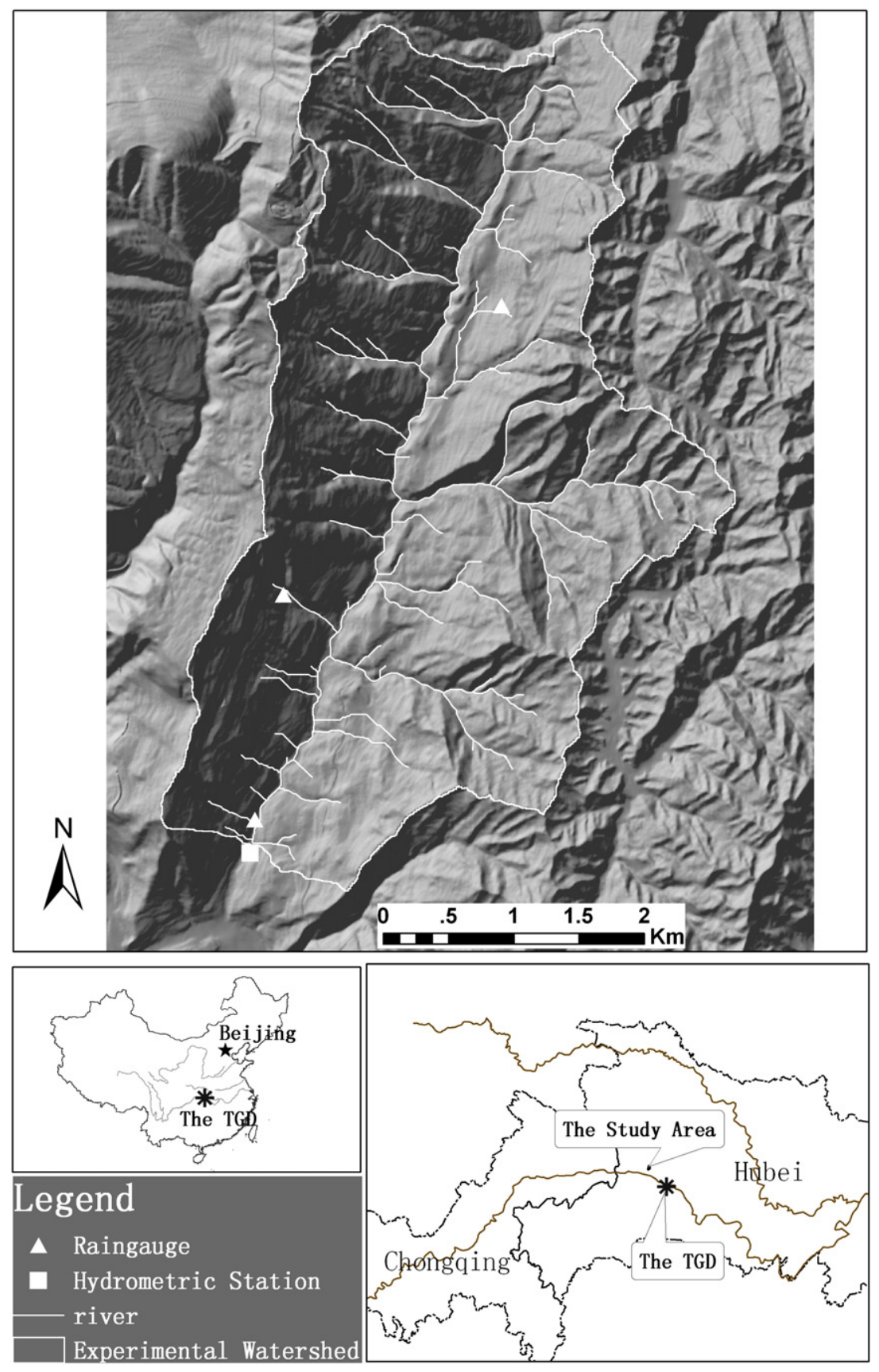

Fig. 1. Location of the study watershed in the TGA of China. 
Table 1

Rainfall characteristics during the study period

\begin{tabular}{|c|c|c|c|c|c|c|c|}
\hline Rainfall depth (mm) & $0-10$ & $10-20$ & $20-30$ & $30-40$ & $40-50$ & $50-60$ & $>60$ \\
\hline \multicolumn{8}{|l|}{ 1989, 1990, and 1993} \\
\hline No. of events & 221 & 42 & 14 & 8 & 7 & 4 & 5 \\
\hline $\begin{array}{l}\text { No. of events generating runoff } \\
\text { 1994-1996 }\end{array}$ & 5 & 16 & 14 & 8 & 7 & 4 & 5 \\
\hline No. of events & 266 & 37 & 18 & 13 & 8 & 5 & 6 \\
\hline No. of events generating runoff & 9 & 19 & 18 & 13 & 8 & 5 & 6 \\
\hline
\end{tabular}

method has been widely used in China (Huang et al., 2007; Shi et al., 2007), although its precision has been argued. The selection of a proper Ia/S value is crucial to accurate estimation of direct runoff from the SCS-CN method (Jain et al., 2006). Thus, the objectives of this study were: (1) to determine the initial abstraction ratio $(I a / S)$, in an experimental watershed in the TGA, by analyzing measured rainfallrunoff events; (2) to compare the performance of the traditional and modified $I a / S$ values with observed rainfall-runoff data. We improved upon the SCS-CN method, rather than developing a new approach, because this method is widely used, and modifications to that method could be readily implemented in China (Huang et al., 2006).

\section{Materials and methods}

\subsection{The study area}

The study was conducted in the Wangjiaqiao watershed $\left(31^{\circ} 5^{\prime} \mathrm{N}-\right.$ $31^{\circ} 9^{\prime} \mathrm{N}, 110^{\circ} 40^{\prime} \mathrm{E}-110^{\circ} 43^{\prime} \mathrm{E}$ ) which lies in Zigui County of Hubei Province, China. It is about $50 \mathrm{~km}$ northwest of the Three-Gorge Dam (TGD) and covers an area of 1670 ha (Fig. 1). Elevations within the watershed range from $184 \mathrm{~m}$ to $1180 \mathrm{~m}$ with slopes ranging from $2^{\circ}$ to $58^{\circ}$ and average of $23^{\circ}$. The length of the main channel is $6496 \mathrm{~m}$, and streams have a trellis drainage pattern. The average annual runoff is $390 \mathrm{~mm}$. The baseflow reaches a minimum value $(0.008-$ $\left.0.024 \mathrm{~m}^{3} \mathrm{~s}^{-1}\right)$ in late winter and a maximum $\left(0.062-0.142 \mathrm{~m}^{3} \mathrm{~s}^{-1}\right)$ in summer. Its annual average temperature is $18{ }^{\circ} \mathrm{C}$, with an average summer high of $28{ }^{\circ} \mathrm{C}$ in July and an average winter low of $8{ }^{\circ} \mathrm{C}$ in January. Annual precipitation averages $1016 \mathrm{~mm}$, of which 70\% occurs between May and September. Snow is infrequent within the watershed. Two main soil great groups occur in the study watershed, namely, purple soil derived from purple sandy shale and paddy soil developed from the purple soil. Purple soil is commonly found in the TGA and estimated to be about 78.7\% of the total cropland (Du and Shi, 1994). According to the Soil Taxonomy of U.S.D.A., the purple soil and paddy soil are classified into Entisols and Aquepts, respectively. The major agricultural crops are rice (Oryza sativa L.), wheat (Triticum aestivum L.), rape (Brassica napus L.), sweet potato (Ipomoea batatas L.), and oranges (Citrus sinensis L.). The Wangjiaqiao watershed is representative of the TGA. Natural resources, land use patterns and population densities in the study watershed are typical of the surrounding region Though the results presented in this paper were derived from a small watershed within the TGA, they give an indication of possible trends occurring throughout the TGA.

\subsection{Data collection}

A set of instruments consisting of continuous recording rain gauge, water level stage recorder and silt sampler (bottle type) were used to record rainfall, stream flow and sediment flow, respectively. Watershed runoff and rainfall data were collected in the years 19891996, however, data of 1991 and 1992 were excluded our study due to its quality. In this study, the observed dataset of rainfall and runoff for an 8-year period (1989-1996) was split into two groups except 1991 and 1992. The data from 1994 to 1996 were used for determining the initial abstraction ratio (Ia/S), and the data for the years 1989, 1990 and 1993 were used for parameter validation. During the study years, rainfall amount ranged from 0.1 to $85.9 \mathrm{~mm}$ per rainstorm, with the distribution shown in Table 1, for a total number of 654 rainfall events. All rainfall events larger than $20 \mathrm{~mm}$ generated runoff.

A reconnaissance field survey was carried out in 1995. Topographic map was used in combination with aerial photographs of appropriate scale. Land use units were delineated on the photographs and verified in the field, and the land uses and the corresponding percentages are shown in Table 2. Due to the completely different soil and crop management practices in paddy field as compared to the other agricultural land, paddy field was listed alone. Cropping and tillage history (1990-1996) of each land use unit were recorded. Soils were mapped by delineating units on the aerial photographs and subsequently verified on the ground. Soil profile descriptions were recorded according to the soil survey manual (Editorial Committee, 1996). A total of 32 soil samples for soil properties analysis were taken with at least one set of soil sample taken from each mapping unit. The land uses and hydrologic soil group (HSG) maps for the study watershed are shown in Fig. 2.

\subsection{Calculation of the SCS-CN initial abstraction ratio}

A total of 29 isolated storm events were selected from 1994 to 1996 for determining Ia/S (Table 3). The analysis time step was $10 \mathrm{~min}$. The selection criteria were (Hawkins et al., 2002; Baltas et al., 2007): (1) storm events with discontinuous rainfall excluded; (2) the peak flow rate of the hydrograph should be than $0.2 \mathrm{~m}^{3} \mathrm{~s}^{-1}$. A lower peak value in a watershed area of $16.7 \mathrm{~km}^{2}$ indicates an insignificant event for analysis; (3) only "larger" storms were used, and its antecedent runoff condition (ARC) of the watershed should be average or high, ARC II or III, correspondingly. This was done to avoid the biasing effects of small storms towards high curve numbers; (4) uniform spatial distribution of rainfall at the extent of the watershed.

The procedure for the determination of the initial abstraction ratio $(I a / S)$ for each event was the following. Firstly, the direct runoff $Q$ in $\mathrm{mm}$ was calculated by dividing the total direct runoff volume of the event by the total area of the watershed. The separation baseflow was used a program "BFLOW.EXE" (http://www.brc.tamus.edu/swat/ soft_baseflow.html), which was based on the method of Arnold and Allen (1999). Fig. 3 displays the estimated baseflow and direct runoff hydrograph from 1994 to 1996. Fig. 4 shows a detailed hydrograph separation for storm event of 17 October 1994. Then, concurrent synchronized break-point records of both rainfall and runoff depth were required, and the storm rainfall depth when direct runoff started was considered the initial abstraction (Ia) value. With the known values of event rainfall, direct runoff, and initial abstraction (Ia), $S$ was obtained from Eq. (4). Finally, after dividing Ia by $S$, a unique initial abstraction ratio was obtained for each storm event. The median value of these ratios for all storm events was used as a representative value for watershed. This procedure is portrayed in the Fig. 5.

\subsection{Comparing estimated runoff results}

To evaluate the predictive ability of SCS-CN method with traditional and modified $I a / S$ values, the direct runoff was calculated using 59 rainfall-runoff events in 1989, 1990 and 1993. Comparisons

Table 2

The land use of the experimental watershed

\begin{tabular}{lcc}
\hline Land use & Area (ha) & Percentage (\%) \\
\hline Forest & 743.2 & 44.5 \\
Shrub land & 53.4 & 3.2 \\
Paddy field & 330.7 & 19.8 \\
Agricultural land & 459.2 & 27.5 \\
Rural residential land & 65.5 & 3.9 \\
Unpaved road & 6.3 & 0.4 \\
Water body & 11.7 & 0.7 \\
\hline
\end{tabular}



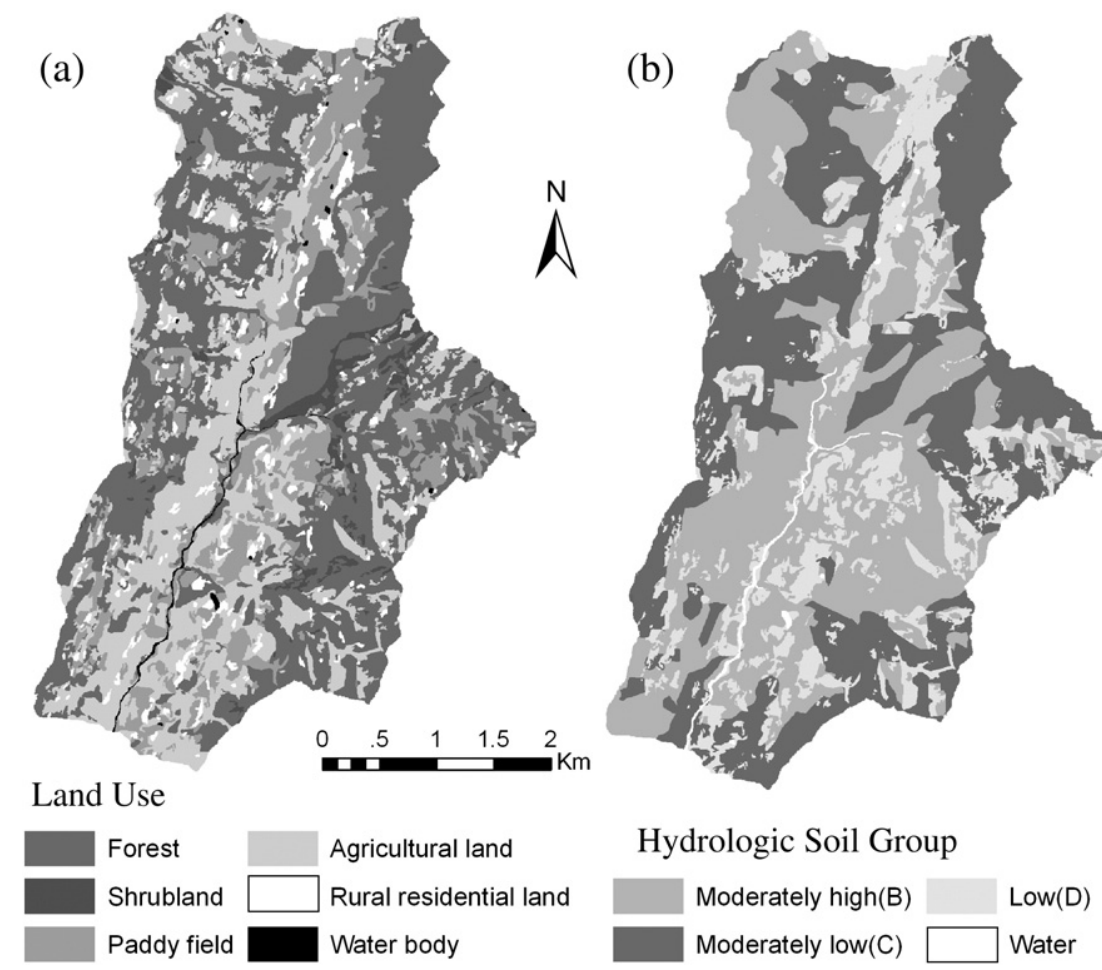

Fig. 2. Land uses (a) and hydrologic soil group (b) maps for the study watershed.

between the runoff depths measured and estimated by SCS-CN method with two Ia/S values were done with the coefficient of determination $R^{2}$, the slope and intercept of the regression equations (procedure Regression in SPSS), and the model efficiency coefficient $(E)$. The expression for $E$ (Nash and Sutcliffe, 1970) is given as:

$E=1-\frac{\sum_{i=1}^{n}\left(Q_{\mathrm{p} i}-Q_{\mathrm{i}}\right)^{2}}{\sum_{i=1}^{n}\left(Q_{\mathrm{i}}-Q_{\text {ave }}\right)^{2}}$

where, $n$ is the total number of observations; $Q_{i}$ is the $i^{\text {th }}$ observed runoff depth; $Q_{\mathrm{ave}}$ is the mean of observed runoff depth; $Q_{\mathrm{pi}}$ is the $i^{\text {th }}$ predicted runoff depth. The model efficiency coefficient, $E$, is commonly used as a measure of model performance in hydrology (Loague and Freeze, 1985). Generally, $E$ is much less than $R^{2}$. The value of $E$ can vary from 1 , when there is a perfect agreement, to $-\infty$. Lower $E$ values indicate that model predictions are worse than predictions using a constant equal to the average observed value. The $E$ is a much superior measure of goodness-of-fit for model validation purposes compared with the familiar $R^{2}$ or the coefficient of determination (Legates and McCabe, 1999).

\section{Results and discussion}

\subsection{Initial abstraction ratio based on rainfall-runoff event analysis}

Twenty-nine storm events were analyzed according to rainfallrunoff processes, and it was found that $I a / S$ ratios varied greatly between storms within watershed. The calculated Ia/S values varied from 0.010 to 0.154 , with a median of 0.048 . The average initial abstraction ratio of the watershed was equal to 0.052 (Table 3). Fig. 6 shows that the $(\mathrm{Ia} / \mathrm{S})$ ratio is predominantly around 0.05 and is not related to rainfall depth $P$. It is obvious that a more appropriate value of $I a / S$ would be in about 0.05 in the TGA.
Similar results, concerning the low Ia/S value, have resulted from other studies. Hawkins et al. (2002) used event analysis and model fitting methods to determine the ratio of Ia to $S$ with rainfall-runoff data from 307 watersheds or plots and a total of 28301 events in USA.

Table 3

Selected storm events between 1994 and 1996

\begin{tabular}{|c|c|c|c|c|c|c|}
\hline \multirow[t]{2}{*}{ No. } & \multirow{2}{*}{$\begin{array}{l}\text { Storm } \\
\text { Event }\end{array}$} & \multirow{2}{*}{$\frac{\text { Rainfall }}{P(\mathrm{~mm})}$} & \multirow{2}{*}{$\frac{\text { Direct runoff }}{Q(\mathrm{~mm})}$} & \multirow{2}{*}{$\frac{\text { Initial abstract }}{I a(\mathrm{~mm})}$} & \multirow{2}{*}{$\frac{\text { Retention }}{S(\mathrm{~mm})}$} & \multirow{2}{*}{$\frac{\text { Ratio }}{\text { Ia/S }}$} \\
\hline & & & & & & \\
\hline 1 & $03 / 05 / 1994$ & 11.2 & 0.36 & 4.6 & 114.1 & 0.040 \\
\hline 2 & $14 / 06 / 1995$ & 11.9 & 0.16 & 6.5 & 176.9 & 0.037 \\
\hline 3 & $24 / 04 / 1994$ & 14.2 & 0.23 & 8.6 & 130.7 & 0.066 \\
\hline 4 & $12 / 05 / 1995$ & 19.0 & 0.01 & 16.8 & 481.8 & 0.032 \\
\hline 5 & $16 / 04 / 1995$ & 19.8 & 0.47 & 9.9 & 200.0 & 0.050 \\
\hline 6 & 10/09/1995 & 22.0 & 0.03 & 18.1 & 503.1 & 0.036 \\
\hline 7 & 01/06/1995 & 23.6 & 0.29 & 14.8 & 258.7 & 0.057 \\
\hline 8 & 17/10/1995 & 24.1 & 0.48 & 13.6 & 218.0 & 0.062 \\
\hline 9 & 09/05/1994 & 26.5 & 0.65 & 13.1 & 262.8 & 0.050 \\
\hline 10 & 19/05/1995 & 27.1 & 1.78 & 10.0 & 146.9 & 0.068 \\
\hline 11 & 19/06/1996 & 28.3 & 2.18 & 13.4 & 86.9 & 0.154 \\
\hline 12 & 20/06/1995 & 30.8 & 4. 02 & 8.3 & 103.4 & 0.080 \\
\hline 13 & 29/07/1996 & 31.7 & 0.92 & 10.7 & 458.3 & 0.023 \\
\hline 14 & 23/06/1996 & 32.3 & 1.27 & 6.1 & 514.7 & 0.012 \\
\hline 15 & 28/06/1996 & 32.4 & 1.75 & 14.6 & 163.3 & 0.089 \\
\hline 16 & 14/05/1996 & 36.1 & 3.45 & 8.9 & 187.2 & 0.048 \\
\hline 17 & $18 / 04 / 1994$ & 38.1 & 3.72 & 10.4 & 178.6 & 0.058 \\
\hline 18 & 19/10/1995 & 41.2 & 1.75 & 8.6 & 574.0 & 0.015 \\
\hline 19 & 26/08/1994 & 48.1 & 1.08 & 19.0 & 755.2 & 0.025 \\
\hline 20 & 04/06/1994 & 49.7 & 2.88 & 9.3 & 525.7 & 0.018 \\
\hline 21 & 04/11/1996 & 49.8 & 4.15 & 6.7 & 405.1 & 0.017 \\
\hline 22 & 07/07/1995 & 51.9 & 11.25 & 12.1 & 100.9 & 0.120 \\
\hline 23 & 02/07/1996 & 54.0 & 2.86 & 7.4 & 714.0 & 0.010 \\
\hline 24 & 02/05/1996 & 57.7 & 5.34 & 21.6 & 207.8 & 0.104 \\
\hline 25 & 03/06/1996 & 62.1 & 3.23 & 18.5 & 544.6 & 0.034 \\
\hline 26 & 07/06/1994 & 68.6 & 11.87 & 11.3 & 219.2 & 0.052 \\
\hline 27 & 09/04/1994 & 73.7 & 9.94 & 14.1 & 297.6 & 0.047 \\
\hline 28 & 18/09/1996 & 82.3 & 15.70 & 16.7 & 208.6 & 0.082 \\
\hline 29 & 03/07/1996 & 85.9 & 21.31 & 7.8 & 208.1 & 0.037 \\
\hline
\end{tabular}



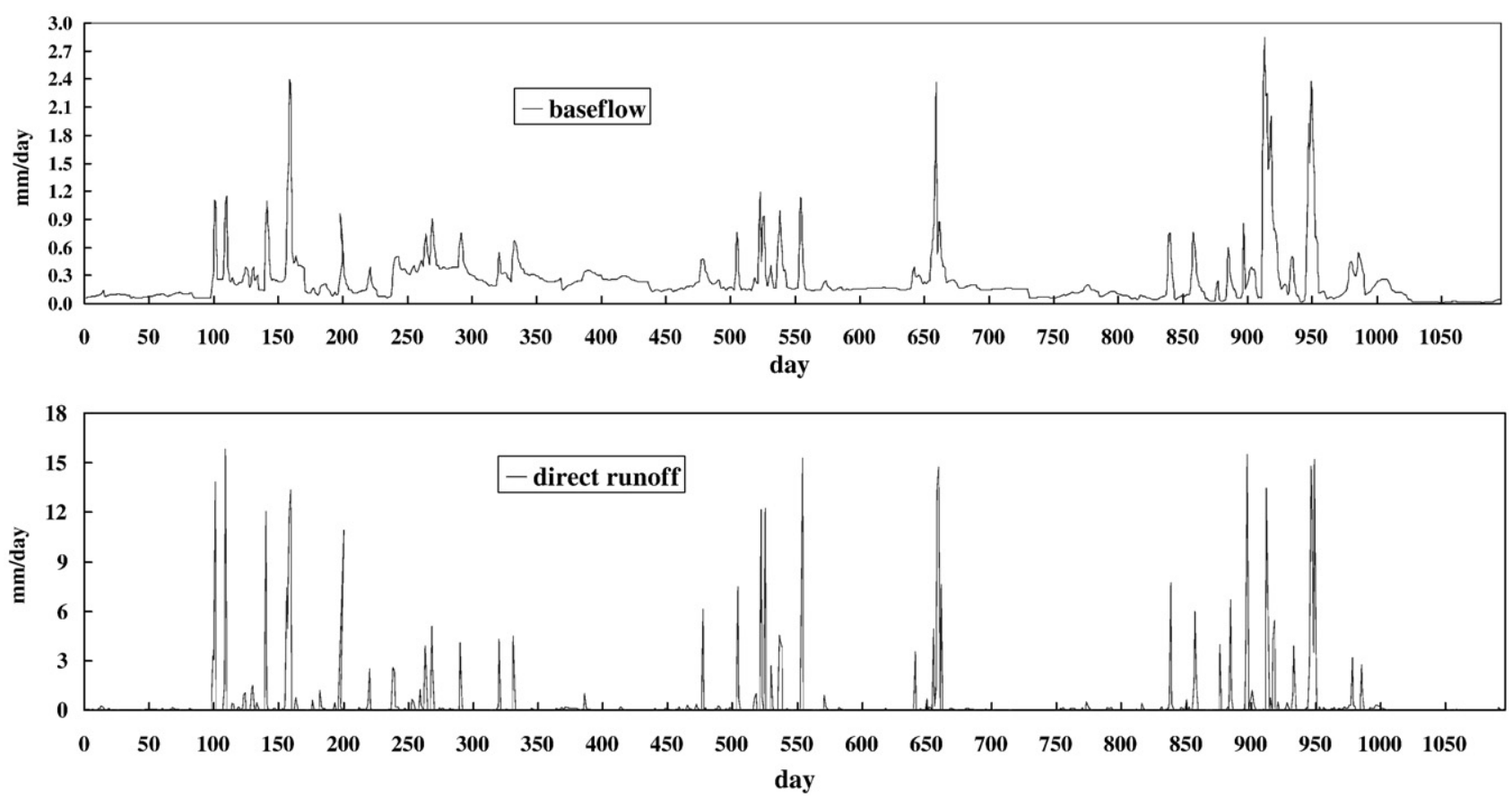

Fig. 3. The direct runoff and baseflow from 1994 to 1996 in Wangjiaqiao watershed.

According to the event analysis, the values of $I a / S$ ratio varied from 0.0005 to 0.4910 , with a median of 0.0476 . More than $90 \%$ of $I a / S$ ratios were less than 0.2. Results from model fitting were more varied than those from event analysis. Ia/S ratios for natural data ranged from 0 to 0.996 , with a median of 0 , and $I a / S$ ratios for ordered data ranged from 0 to 0.9793 with a median of 0.0618 . Hawkins et al. (2002) suggest changing the $I a / S$ ratio from 0.2 to 0.05 for use in runoff calculations. Based on recent investigations, Baltas et al. (2007) using observed rainfall-runoff events determined initial abstraction ratio $(I a / S)$ in an experimental watershed in Greece. The average ratio $(\mathrm{I} / \mathrm{S})$ was equal to 0.014; the maximum value was 0.037 and the minimum 0.004. Lim et al. (2006) explored the effects of initial abstraction and urbanization on estimated direct runoff. The results indicated that the use of a $5 \%$ Ia/S value with modified $\mathrm{CN}$ values for a $5 \% \mathrm{Ia} / \mathrm{S}$ value and hydrologic soil group D for urbanized areas can improve long term direct runoff estimation.

The initial abstraction consists mainly of interception, infiltration during early stages of the storm, and surface depression storage (SCS, 1972). The antecedent runoff condition (ARC) of the selected 29 rainfall-runoff events was classified as ARC II (average) or III (high)

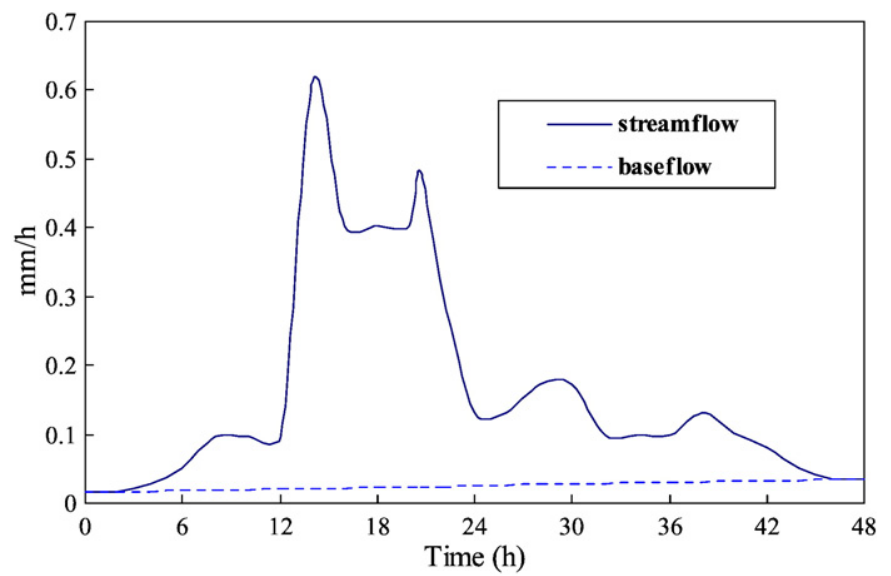

Fig. 4. The separation baseflow for storm event of 17 October 1994. and contributed to the low amount of initial abstraction. Initial abstraction is proportional to retention, and the watershed retention increases with rainfall. This is mainly attributed to the complex landscape characteristics in the study watershed. Unlike agricultural areas in the United States, agricultural watersheds in the TGA of China contain large areas of forest and paddy fields. Paddy fields cover around $19.8 \%$ of the watershed, and reduce downstream flooding due to their ability of retaining runoff water (Kang et al., 2006). The forested areas have steep slopes, contain a variety of tree types, and remain undisturbed. Since undisturbed forest areas plays an important role in the interception of rainfall and the retention of water with forest litter layers. Additionally, soil parent materials of the entire watershed are purple sandy shale, which is characterized by easy physical weathering and broken up by anthropic activities into rock fragments or gravels, thus these make rainfall fast infiltration into deeper layers and increase their storage capacity.

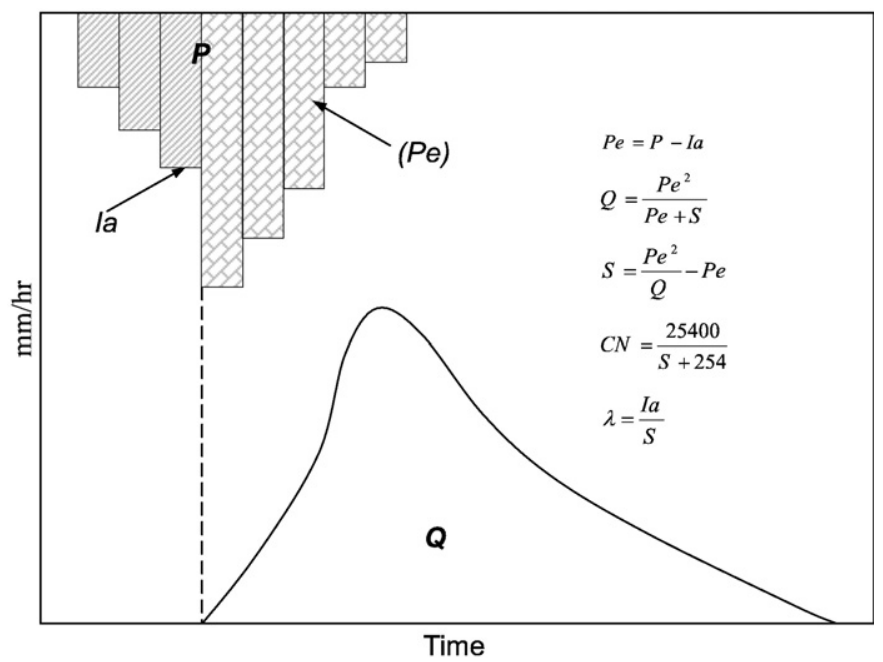

Fig. 5. Event analysis method (Hawkins et al., 2002). 


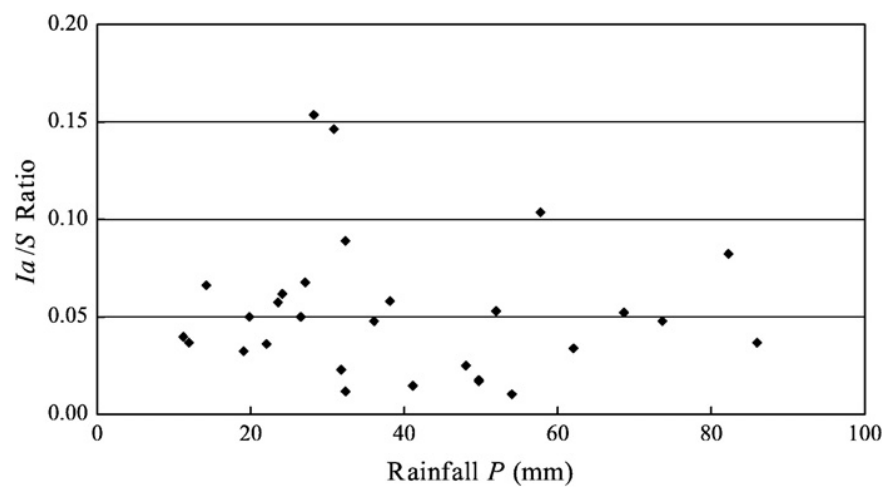

Fig. 6. Initial abstraction ratio $(I a / S)$ versus rainfall depth $(P)$ for each event.

\subsection{Effects of Ia/S values on runoff estimation}

\subsubsection{Traditional Ia/S value}

Runoff depths were calculated from the $\mathrm{CN}$ values of the previous investigations in the Yangtze River Basin (Gao et al., 2006; RWCSCB, 1998; Shi et al., 2002) and the SCS handbook (SCS, 1972) for each rainstorm event, according to hydrologic and antecedent soil moisture conditions, and were compared with the corresponding observed runoff depths. Fig. 7a shows that the standard SCS-CN method underestimates large runoff events, but overestimates some of the small events. Table 4 shows that the standard SCS-CN method yielded a slope of the regression line of 0.559 and an intercept of 0.301 , which confirms the under prediction observed in Fig. 7a. A similar underestimation of the $\mathrm{CN}$ value, based on the SCS handbook table, has also been reported (Van Mullen 1991; King et al., 1999).

\subsubsection{Modified Ia/S value}

Based on the result of rainfall-runoff event analysis in the study watershed, use of an $I a / S$ ratio of 0.05 rather than the commonly used value of 0.2 would be appropriate. Thereby, Eq. (4) becomes

$Q=\frac{(P-0.05 S)^{2}}{P+0.95 S} \quad$ for $P>0.05 S$

However, if a relationship different from $I a=0.2 S$ is used, a new set of curve numbers must be developed (Hawkins et al., 2002), because the value of $\mathrm{S}$ with a $0.05 \mathrm{Ia} / \mathrm{S}$ value is not the same as the one used in estimating direct runoff with a 0.2 Ia/S value. Hawkins et al. (2002) determined a relationship that permits conversion from the 0.20 based $\mathrm{CN}$ to 0.05 -based $\mathrm{CN}$ from model fitting results using rainfallrunoff data from 307 watersheds.

$S_{0.05}=1.33 S_{0.20}^{1.15}$

$\mathrm{CN}_{0.05}=\frac{100}{1.879\left[\frac{100}{\mathrm{CN}_{0.20}}-1\right]^{1.15}+1}$

where $S_{0.05}$ and $S_{0.2}$ are in inches. $S_{0.05}$ and $\mathrm{CN}_{0.05}$ are the storage and $\mathrm{CN}$ values with a $0.05 \mathrm{Ia} / \mathrm{S}$ ratio, and $\mathrm{S}_{0.20}$ and $\mathrm{CN}_{0.20}$ are the values with a $0.2 \mathrm{Ia} / \mathrm{S}$ ratio. The conjugate $\mathrm{CN}$ values $\left(\mathrm{CN}_{0.20}\right.$ and $\left.\mathrm{CN}_{0.05}\right)$ were computed with corresponding storage values $\left(S_{0.20}\right.$ and $\left.S_{0.05}\right)$ using Eq. (8b).

Comparison of Fig. 7a with Fig. $7 \mathrm{~b}$ indicates that runoff predicted by Eq. (7) is in better agreement with observed runoff values. From Table 4 we can see that, for all runoff data, the slope of the regression line has increased to 0.834 compared with 0.559 for traditional $I a / S$ value. Use of Eq. (7) improved model efficiency coefficient $(E)$ to 0.768 compared with 0.482 for traditional $I a / S$ value. For the calibration method proposed for SWAT model by Santhi et al. (2001), an E value greater than 0.50 was deemed acceptable for model calibration. Thus,
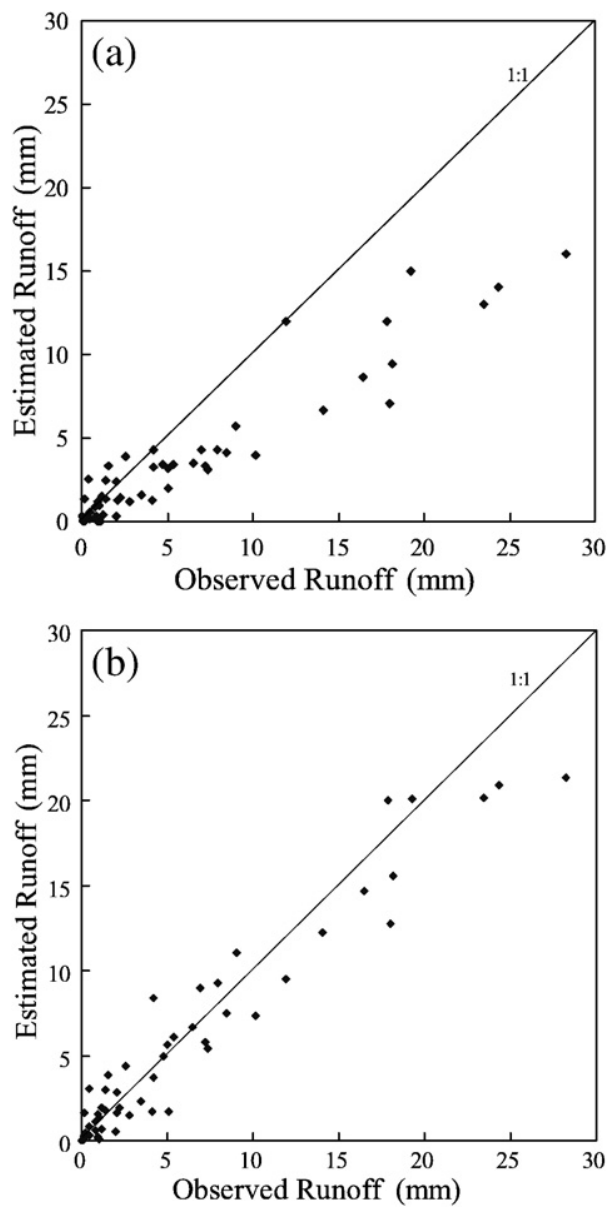

Fig. 7. Observed versus predicted runoff depth by (a) 0.2 and (b) $0.05 \mathrm{Ia} / \mathrm{S}$ Values.

improvements in SCS-CN predictive ability may be expected with a $0.05 \mathrm{Ia} / \mathrm{S}$ value. However, Eq. (7) also results in over prediction for small events (intercept is 0.236), which might be inherent to the SCS method of defining the rainfall versus runoff relationship. For small storm events, Bondelid et al. (1982) found the SCS-CN method to be highly sensitive to the antecedent soil moisture condition; this parameter is not clearly defined. Further improvements may be considered the effects of antecedent soil moisture condition, rainfall intensity or duration on runoff (Mishra et al., 2006a,b; Huang et al., 2007).

\section{Conclusions}

The initial abstraction ratio $(I a / S)$ in SCS-CN equation was determined using rainfall-runoff event analysis from an agricultural watershed in the TGA of China. The results indicated that the Ia/S values varied from 0.010 to 0.154 , with a median of 0.048 . The average initial abstraction ratio of the watershed was equal to 0.052 . This is mainly attributed to the landscape and geological characteristics in the study watershed. A comparison between standard and modified $I a / S$ values showed that modified $I a / S$ value improved the agreement between measured and predicted direct runoff to a high degree. The

Table 4

Runoff depth predicted by the SCS-CN method with and without adjustment for $I a / S$

\begin{tabular}{llllll}
\hline Ia/S & \multicolumn{2}{l}{ Linear regression statistic } & & Model efficiency coefficient \\
\cline { 2 - 3 } & Intercept & Slope & $R^{2}$ & & $(E)$ \\
\hline 0.20 & 0.301 & 0.559 & 0.771 & 0.482 \\
0.05 & 0.236 & 0.834 & 0.804 & 0.768 \\
\hline
\end{tabular}


standard SCS-CN method underestimates large runoff events, yielded a slope of the regression line of 0.559 and an intercept of 0.301 . The modified $I a / S$ value was about 0.05 that better predicted runoff depths with an $R^{2}$ of 0.804 and a linear regression slope of 0.834 . It also improved model efficiency coefficient $(E)$ to 0.768 compared with 0.482 for traditional $I a / S$ value. Improvements in SCS-CN predictive ability may be expected with a $0.05 \mathrm{Ia} / \mathrm{S}$ value in the TGA of China.

\section{Acknowledgements}

Financial support for this research was provided by the National Natural Science Foundation of China (No. 40671178), the Key Project of Chinese Academy of Sciences (No. KZCX2-YW-421) and the Key Project of Chinese Ministry of Education (No. 108165).

\section{References}

Arnold, J.G., Allen, P.M., 1999. Automated methods for estimating baseflow and ground water recharge from streamflow records. Journal of the American Water Resources Association 35, 411-424.

Arnold, J.G., Williams, J.R., Srinivasan, R., King, K.W., 1996. SWAT: Soil and Water Assessment Tool. USDA-ARS, Grassland, Soil and Water Research Laboratory, Temple, TX.

Baltas, E.A., Dervos, N.A., Mimikou, M.A., 2007. Determination of the SCS initial abstraction ratio in an experimental watershed in Greece. Hydrology and Earth System Sciences $11,1825-1829$.

Bondelid, T.R., McCuen, R.H., Jackson, T.J., 1982. Sensitivity of SCS models to curve number variation. Water Resources Bulletin 18, 111-116.

Du, R.H., Shi, D.M., 1994. The impact of soil and water losses upon ecosystem and environment in the Three Gorge Area of the Changjiang River. Chinese Since Press, Beijing. (In Chinese).

Editorial Committee, 1996. Soil physical and chemical analysis and description of soil profiles. Standards Press of China, Beijing. (In Chinese).

Gao, Y., Zhu, B., Miao, C.Y., Zhang, J., 2006. Application of SCS-CN method to estimate the runoff on sloping field of Purple Soil. Chinese Agricultural Science Bulletin 22, 396-400 (in Chinese with English abstract).

Grayson, R.B., Moore, I.D., McMahon, T.A., 1992. Physically based hydrologic modelling 2. Is the concept realistic? Water Resources Research 28, 2659-2666.

Hawkins, R.H., Jiang, R., Woodward, D.E., Hjelmfelt, A.T., Van Mullem, J.A., Quan, Q.D. 2002. Runoff curve number method: examination of the initial abstraction ratio. Proceedings of the Second Federal Interagency Hydrologic Modeling Conference, Las Vegas, Nevada. U.S. Geological Survey, Lakewood, Colorado. CD-ROM.

Huang, M.B., Gallichand, J., Dong, C.Y., Wang, Z.L., Shao, M.A., 2007. Use of soil moisture data and curve number method for estimating runoff in the Loess Plateau of China. Hydrological Processes 21, 1471-1481.

Huang, M.B., Gallichand, J., Wang, Z.L., Goulet, M., 2006. A modification to the soil conservation service curve number method for steep slopes in the Loess Plateau of China. Hydrological Processes 20, 579-589.

Jain, M.K., Mishra, S.K., Babu, P.S., Venugopal, K., 2006. On the Ia-S relation of the SCS-CN method. Nordic Hydrology 37, 261-275.

Kang, M.S., Park, S.W., Lee, J.J., Yoo, K.H., 2006. Applying SWAT for TMDL programs to a small watershed containing rice paddy fields. Agricultural Water Management 79, $72-92$.
King, K.W., Arnold, J.G., Bingner, R.L., 1999. Comparison of Green-Ampt and curve number methods on Goodwin Creek watershed using SWAT. Transactions of the ASAE 42, 919-925.

Knisel, W.G., 1980. CREAMS: a field-scale model for chemical, runoff and erosion from agricultural management systems. Conservation Research Report, vol. 26. South East Area, US Department of Agriculture, Washington, DC.

Legates, D.R., McCabe, G.J., 1999. Evaluating the use of "goodness-of-fit" measures in hydrologic and hydroclimatic model validation. Water Resources Research 35, 233-241.

Lim, K.J., Engel, B.A., Muthukrishnan, S., Harbor, J., 2006. Effects of initial abstraction and urbanization on estimated runoff using $\mathrm{CN}$ technology. Journal of the American Water Resources Association 42, 629-643.

Loague, K.M., Freeze, R.A., 1985. A comparison of rainfall-runoff modeling techniques on small upland catchments. Water Resources Research 21, 229-248.

Lu, X.X., Higgitt, D.L., 1998. Recent changes of sediment yield in the Upper Yangtze, China. Environmental Management 22, 697-709.

Mishra, S.K., Sahu, R.K., Eldho, T.I., Jain, M.K., 2006a. An improved Ia-S relation incorporating antecedent moisture in SCS-CN methodology. Water Resources Management 20, 643-660.

Mishra, S.K., Tyagi, J.V., Singh, V.P., Singh, R., 2006b. SCS-CN based modeling of sediment yield. Journal of Hydrology 324, 301-322.

Nash, J., Sutcliffe, J., 1970. River flow forecasting through conceptual models, 1. A discussion of principles. Jounal of Hydrology 10, 282-290.

Ponce, V.M., Hawkins, R.H., 1996. Runoff curve number: has it reached maturity? Journal of Hydrologic Engineering - ASCE 1, 11-19.

Reshmidevia, T.V., Janab, R., Eldho, T.I., 2008. Geospatial estimation of soil moisture in rain-fed paddy fields using SCS-CN-based model. Agricultural Water Management 95, 447-457.

RWCSCB (Rural Water Conservancy and Soil Conservation Bureau, Changiiang River Water Resources Commission), 1998. Technologic manual of soil and water conservation of Changjiang basin. Standards Press of China, Beijing. (In Chinese).

Santhi, C., Arnold, J.G., Williams, J.R., Drugs, W.A., Srinivasan, R., Hauck, L.M., 2001. Validation of the SWAT model on a large river basin with point and nonpoint sources. Journal of the American Water Resources Association 37, 1169-1188.

SCS (Soil Conservation Service), 1972. SCS National Engineering Handbook, Section 4. Hydrology, Soil Conservation Service. US Department of Agriculture, Washington, DC.

Sharpley, A.N., Williams, J.R., 1990. EPIC-Erosion/Productivity Impact Calculator: 1. Model Documentation. US Department of Agriculture Technical Bulletin, vol. 1768. US Government Printing Office, Washington, DC.

Shi, Z.H., Cai, C.F., Ding, S.W., Li, Z.X., 2002. Research on nitrogen and phosphorus load of agricultural non-point sources in middle and lower reaches of Hanjiang River. Acta Scientiae Circumstantiae 22, 473-477 (in Chinese with English abstract).

Shi, D.M. Yang, Y.S., Lu, X.X, Liang, Y. 1992. The analysis of soil erosion pattern and sediment sources in the Three Gorges Area of the Yangtze River. Chinese Journal of Soil and Water Conservation 5, 9-21 (in Chinese with English abstract).

Shi, P.J., Yuan, Y., Zheng, J., Wang, J.A., Ge, Y., Qiu, G.Y., 2007. The effect of land use/cover change on surface runoff in Shenzhen region, China. Catena 69, 31-35.

Singh, P.K., Bhunya, P.K., Mishra, S.K., Chaube, U.C., 2008. A sediment graph model based on SCS-CN method. Journal of Hydrology 349, 244-255.

Van Mullen, J.A., 1991. Runoff and peak discharges using Green-Ampt infiltration model. Journal of Hydraulic Engineering - ASCE 117, 354-370.

Young, R.A., Onstad, C.A., Bosch, D.D., Anderson, W.P., 1989. AGNPS: a nonpoint-source model for evaluating agricultural watersheds. Journal of Soil and Water Conservation 44, 168-173. 